\title{
SUNFLOWER BREEDING FOR RESISTANCE TO THE NEW BROOMRAPE RACE IN THE KRASNODAR REGION OF RUSSIA
}

\author{
Gontcharov, S.V."
}

Kuban State Agrarian University, Kalinina, 13, Krasnodar, 350044, Russia

Received: July 15, 2009 Accepted: November 10, 2009

SUMMARY

Broomrape (Orobanche cumana Wallr.) is a parasitic plant, feeding on sunflower roots. In recent years some new, more aggressive broomrape races have been found in different parts of the world (Spain, Turkey, Romania, etc.). Soon afterwards they occurred in Russia and we started a special breeding program to control the parasites. A line (VK 623) resistant to race $\mathrm{F}$ was previously found among the lines from the VNIIMK breeding program. Several new prospective sunflower inbred lines with resistance to both broomrape races, E and F, were developed in a short time. Now they are being converted to cmslines. However, the recessive character of their resistance creates some difficulties in commercial sunflower hybrid breeding, so, to obtain new donors of resistance, the cultivated sunflower was crossed with $H$. tuberosus (used as pollinator).

Key words: breeding, broomrape, hybrid, resistance, sunflower

\section{INTRODUCTION}

Broomrape (Orobanche cumana Wallr. syn. O. cernua Loefl.) is a parasitic plant, feeding on sunflower roots. It is widely spread on the territory of the former USSR, southern Europe, Middle East and China (Parker, 1994). Up to the present, the main method of controlling broomrape was development of resistant hybrids and/or OP varieties. Now Clearfield technology is also important and prospective. Majority of hybrids and OP varieties released in Russia are resistant to race E, but the broomrape continues to produce new races. The aim of our work was to find donors of resistance to the new races of broomrape, to develop new sunflower inbred lines with improved broomrape resistance and to start a new breeding program for transferring the broomrape resistance from perennial sunflower species to the cultivated sunflower.

* Corresponding author: e-mail: serggontchar@hotmail.com 


\section{MATERIAL AND METHODS}

Broomrape (Orobanche cumana Wallr. syn. O. cernua Loefl.) seeds (mixture of undefined races) were collected from sunflower fields in Russia (mainly Krasnodar and Rostov regions). Broomrape seeds of race $\mathrm{F}$ were obtained from Spain.

All the inbred lines from the working collection of hybrid sunflower breeding department of All-Russia Research Institute of Oil Crops (VNIIMK) were experimental material used in this study.

Broomrape resistance of sunflower lines was tested in the Immunology Laboratory of VNIIMK. Seeds of the tested sunflower lines were planted into boxes filled with soil artificially infested with broomrape seeds and cultivated for a month. After that sunflower plants were uprooted, their root systems carefully washed and amount of broomrape nodules or stalks registered. Plants without any broomrape nodules or stalks were classified as resistant, others as susceptible.

Different wild populations of Helianthus tuberosus were used as a pollinator for crossing with $\mathrm{cms}$-lines of cultivated sunflower. Two weeks-old embryos were placed in Petri dishes and cultivated under the room temperature. The obtained seedlings were transplanted into the soil.

\section{RESULTS}

As it was published earlier (Gontcharov et al., 2004), all VNIIMK-released and prospective inbred lines are susceptible to the Spanish broomrape (race F) with a single exception - the line VK-623. The number of broomrape plants on the roots of infested sunflower plantlets varied from 0.0 (VK-623) to more than 20 (SL-1) (Table 1). All of the tested inbred lines were completely resistant to race $\mathrm{E}$ of the pathogen.

Table 1: Resistance of sunflower inbred lines to broomrape race F (VNIIMK, Krasnodar, 2001)

\begin{tabular}{lcc}
\hline Line & Infected plants, \% & Degree of attack \\
\hline VK-455 & 67 & 1.2 \\
VK-746 & 100 & 10.1 \\
VK-761 & 100 & 17.0 \\
VK-623 & 0 & 0.0 \\
VK-763 & 100 & 9.6 \\
VK-604 & 100 & 5.8 \\
SL-1 & 100 & 22.9 \\
\hline Average from the all & - & 9.7 \\
tested lines (50 samples) & -
\end{tabular}

All $\mathrm{F}_{1}$ hybrids obtained by crossing VK-623 with other lines were highly susceptible to race $\mathrm{F}$, so this resistance was the recessive one (Table 2). From the breeding material, involving VK-623 as a parental line, fifteen resistant plants were found in 
the $\mathrm{F}_{4}$ progeny of the hybrid combination $14 \mathrm{~B} \times(\mathrm{VK}-623 \times \mathrm{VK}-616)$. All the plants were artificially self-pollinated. The next generation proved the resistance to races $\mathrm{E}$ and $\mathrm{F}$ in the next year testing. As a result, new prospective inbred sunflower lines with resistance to both broomrape races were developed. Now they are being converted to $\mathrm{cms}$-lines.

Table 2: Resistance of $F_{1}$ sunflower hybrids to the broomrape race $F$ (VNIIMK, Krasnodar, 2001)

\begin{tabular}{lcc}
\hline Hybrid & Infected plants, \% & Degree of attack $^{*}$ \\
\hline VK-623 A $\times$ VK-777 & 100 & 9.2 \\
VK-623 A $\times$ VK-788 & 100 & 11.5 \\
VK-680 A $\times$ VK-623 & 100 & 16.3 \\
\hline
\end{tabular}

* - Degree of attack - average number of broomrape nodules on the stalk per sunflower plant

However race $\mathrm{F}$ is not predominant in our region for now. Moreover, there is evidences that new and more aggressive races occurred in recent years. Testing the resistance of the newly-developed lines showed great differences among the broomrape populations from our region. Broomrape resistance of the new lines is significantly improved, but in many cases it is not sufficient (Table 3).

Table 3: Resistance of new sunflower inbred lines to broomrapes of different origin (VNIIMK, Krasnodar, 2007)

\begin{tabular}{lcccccc}
\hline \multirow{2}{*}{ Origin } & \multicolumn{2}{c}{$\begin{array}{c}\text { Krasnodar population } \\
\text { of broomrape (mixture) }\end{array}$} & \multicolumn{2}{c}{$\begin{array}{c}\text { Turkish population } \\
\text { of broomrape }\end{array}$} & \multicolumn{2}{c}{$\begin{array}{c}\text { Rostov population } \\
\text { of broomrape }\end{array}$} \\
\cline { 2 - 7 } & $\begin{array}{c}\text { Infected } \\
\text { plants, } \%\end{array}$ & $\begin{array}{c}\text { Degree } \\
\text { of attack* }\end{array}$ & $\begin{array}{c}\text { Infected } \\
\text { plants, \% }\end{array}$ & $\begin{array}{c}\text { Degree } \\
\text { of attack* }\end{array}$ & $\begin{array}{c}\text { Infected } \\
\text { plants, \% }\end{array}$ & $\begin{array}{c}\text { Degree } \\
\text { of attack }^{*}\end{array}$ \\
\hline BR-34-11-2 & 12 & 1.3 & 75 & 7.0 & 100 & 3.8 \\
BR-34-11-3 & 17 & 1.6 & 80 & 7.0 & 100 & 12.0 \\
BR-34-11-4-1 & 9 & 1.0 & 10 & 1.0 & 81 & 6.6 \\
BR-34-11-4-2 & 38 & 1.2 & 82 & 8.0 & 90 & 3.6 \\
BR-34-11-5-2 & 60 & 4.8 & 64 & 10.0 & 100 & 10.0 \\
BR-34-11-6-2 & 0 & 0.0 & 90 & 5.0 & 20 & 1.5 \\
\hline
\end{tabular}

* - Degree of attack - average number of broomrape nodules on the stalk per sunflower plant

As an alternative way, Genetic Laboratory of VNIIMK started a program of developing Imi-resistant analogues of elite lines to produce new hybrids for the Clearfield technology.

To obtain new donors of resistance in the future, the cultivated sunflower was crossed with $H$. tuberosus (used as a pollinator) at the Genetics and Breeding Department of Kuban State Agrarian University. Pollination was performed in field conditions. We used a male sterile hybrid (cms-pet) as the female parent. Two weeks-old embryos were removed from the heads, placed into Petri dishes and cultivated at room temperature. Some plants of the interspecific $F_{1}$ hybrids have been successfully cultivated. They will be backcrossed to the elite lines of cultivated sunflower. 


\title{
CONCLUSIONS
}

Among the elite and promising VNIIMK inbred lines only one (VK-623) proved to be resistant to the Spanish race of broomrape. Recently, some new and prospective sunflower inbred lines posessing resistance to both broomrape races, $\mathrm{E}$ and $\mathrm{F}$, have been developed. Presently they are being converted to the $\mathrm{cms}$-lines. Occurrence and spreading of new and more aggressive broomrape races make us search for new donors of resistance and different approaches to their use. As an alternative way, Genetic Laboratory of VNIIMK started a program of developing IMI-resistant analogues of the VNIIMK elite sunflower lines. To obtain new donors of resistance in the future, the cultivated sunflower was crossed with $H$. tuberosus (used as a pollinator) at the Genetics and Breeding Department of Kuban State Agrarian University. Some new plants of interspecific $F_{1}$ hybrids have been obtained and successfully cultivated. They will be backcrossed to the elite lines of cultivated sunflower.

\section{REFERENCES}

Antonova, T.S., 1998. The interdependence of broomrape virulence and sunflower resistant mechanisms. Proc. $4^{\text {th }}$ Int. Workshop on Orobanche Research. Albena. Bulgaria, pp. 147 153.

Antonova, T.S., 2000. Modern tendencies in sunflower breeding for pathogen resistance. Nauchno-Technich. Bull. of VNIIMK, Krasnodar, V.123: 3-8. (In Russian).

Gontcharov, S.V., Antonova, T.S., Araslanova, N.M., 2004. Sunflower breeding for resistance to the new broomrape race. Helia, 27(40): 193-198.

Parker C., 1994. The present state of Orobanche problem, In: H. Pieters et al. [Eds.], Biology and Management of Orobanche, Proc. $3^{\text {rd }}$ Int. Workshop on Orobanche and Related Striga Research, Amsterdam, pp. 17-26.

\section{MEJORAMIENTO DEL GIRASOL POR LA RESISTENCIA A UNA NUEVA RAZA DE JOPO EN LA REGIÓN DE KRASNODAR, RUSIA}

\author{
RESUMEN
}

El jopo (Orobanche cumana Wallr.) es una planta parásita, que se alimenta de las raíces del girasol. Durante los últimos años, se encontraron algunas nuevas razas más agresivas en diferentes partes del mundo (España, Turquía, Rumania, etc.). Un poco más tarde aparecieron en Rusia y se empezó un programa de mejoramiento específico. Previamente, una línea resistente (VK 623) a la raza F había sido detectada entre las líneas derivadas de VNIIMK. En poco tiempo, se desarrollaron algunas nuevas líneas endocriadas de girasol con resistencia a ambas razas -E y F- de jopo. Ahora ellas se encuentran en la fase de conversión a líneas androestériles cms. Sin embargo el carácter recesivo de esta resistencia provoca algunas dificultades en el desarrollo de cultivares comerciales de girasol, por lo que en función de obtener nuevos donadores de la resistencia en el futuro, el girasol cultivado fue cruzado con $\mathrm{H}$. tuberosus (utilizado como polinizador). 


\title{
SÉLECTION DE TOURNESOL POUR LA RÉSISTANCE À LA NOUVELLE RACE d'Orobanche DANS LA RÉGION DE KRASNODAR, RUSSIE
}

\author{
RÉSUMÉ
}

L'Orobanche (Orobanche cumana Wallr.) est un parasite végétal se nourrissant des racines de tournesol. Ces dernières années, de nouvelles races plus agressives ont été trouvées dans différentes régions du monde (Espagne, Turquie, Roumanie...).

Elles sont ensuite apparues en Russie et nous avons commencé un programme spécial de sélection. Précédemment, une ligne résistante (VK 623) à la race $\mathrm{F}$ a été trouvée parmi les lignées de sélection de VNIIMK.

En peu de temps, de nouvelles lignées parentales potentielles de tournesol, résistantes aux races $\mathrm{E}$ et $\mathrm{F}$, ont été développées. Actuellement, elles sont sur le point d'être converties en lignées $\mathrm{cms}$.

Cependant, le caractère récessif de cette résistance crée quelques difficultés dans la sélection d'hybrides commerciaux de tournesol : aussi, pour obtenir de nouveaux donneurs de gènes de résistance, des croisements interspécifiques ont été réalisés entre le tournesol cultivé (Helianthus annuus L.) et le topinambour (Helianthus tuberosus), utilisé comme pollinisateur. 
